\title{
The Use of Educational Technology in Teaching and Learning Process Towards Covid 19 Pandemic at Senior High Schools in Palu
}

\author{
Ernitasari Mulyadi ${ }^{1 *}$ Surni Kadir ${ }^{2}$ Fikriani A.Omolu ${ }^{1}$ Rahayu Prasetyaningsih ${ }^{1}$ \\ Normawati $^{2}$ \\ ${ }^{1}$ Faculty of Teacher Training and Education, University of Muhammadiyah Palu, Central Sulawesi 94118, Indonesia \\ ${ }^{2}$ Faculty of Islamic Studies, University of Muhammadiyah Palu, Central Sulawesi 94118, Indonesia \\ *Corresponding author. Email: ernitasarim@yahoo.com
}

\begin{abstract}
The objective of the research is to explore the use of educational technology in the teaching and learning process for Senior High School students in Palu during outbreak of corona virus pandemic. This research is an exploration research to find out the real condition of the teaching and learning process at Senior High Schools. It was conducted at nine senior high schools in Palu. The finding shows that of more than 700 teachers involved in the training for applying educational technology tools, there around 150 teachers are less active to participate in training. Meanwhile, of more than 15.000 students who participated in distance learning, there are around 3000 students could not participate actively.
\end{abstract}

Keywords: Educational technology, teaching and learning, covid 19 pandemic, distance learning

\section{INTRODUCTION}

The spreading of Corona Virus that commonly known as Covid-19 has become a new and more harmful pandemic threats the world. It affects all aspects of human lives; health care of course, economic social interaction, and education. The corona virus has spread to around 191 countries and has threated human survival. In December 2019, a new infectious respiratory disease emerged in Wuhan, Hubei province, China and was named by the World Health Organization as COVID-19 (coronavirus disease 2019). To healthcare, corona virus has trapped healthcare professionals into a lot of difficulties in maintaining the quality of healthcare in these days. There are some massive problems the healthcare professionals face as an impact of coronavirus outbreaks; challenges in the diagnosis, quarantine and treatment of suspected or confirmed case, high burden of functioning of the existing medical system, patient with other diseases problem are getting neglected, overload on doctors and other healthcare professionals who are at a very high risk, overloading of medical shops, requirement for high protection, and disruption of medical supply chain. Economically, the coronavirus spreading has forced the closure of many factories leaded to high rate of unemployment. The flight to and from most countries in the world are restricted, the closure of several business and investment happened all over the countries. The report from The Science of Total Environment article reported that major international flights and also all types of business transports have been deferred amid different countries. Due to lockdown all domestic flights, railway service (except goods trains), bus, truck, and vehicles transports are suspended with special exemption to those associated with essential commodities. In almost all the COVID-19 stricken countries, entire educational, commercial, sports and spiritual institutions are closed. Industries are suffering a lot as many of these excepting those related to essential amenities, are closed for a long time in many countries. Social interaction is one of human of aspects lives where the people are restricted to do communication. They are being involved in social distancing, large scale social limitation, and lockdown. The people should stay at home 
and should work from home (WFM). Commonly, the restriction in social interaction covers service sector is not being able to provide their proper service, cancellation or postponement of large-scale sports and tournaments, avoiding the national and international travelling and cancellation of service, disruption of celebration of culture, religious and festive events, undue stress among the population, social distancing with our peers and family members, closure of hotels, restaurants, and religious places, closure of places for entertainment such as movie and play theatres, sport clubs, gymnasiums, and swimming pool. Wide world educational activities suffered from closure at any level of education institutions. According to UNESCO [1] at the middle April 2020, approximately 1.723 billion learners have been affected due to school closure in response to the pandemic. Meanwhile, it is also important information for the countries to avoid the outbreak of coronavirus pandemic in which UNESCO also reported that it is now providing immediate support to countries to minimize education distruption [2]. In Indonesia, the outbreaks of coronavirus spread out to almost 33 provinces. Indonesia government policy allows schools to conduct national test for secondary school students on 20-23 April, 2020 for around 8,3 million students from 105.000 education unit by implementing the health protocol procedure. In Central Sulawesi, particularly in Palu-the capital of central Sulawesi there were 400 schools being in closure and 50 thousand of different level should study from home. The focus of this research is to explore the advantage and the weakness of Information technology in teaching and learning process during coronavirus pandemic at Secondary High Schools in Palu. The writers argues the advantage and the weakness educational technology in three issues (1) what are the advantages of educational technology in the teaching and learning process toward coronavirus pandemic? (2) How information technology can effectively overcome distance learning?, and (3) What are weaknesses of educational technology for distance learning?

\subsection{Related Work}

According to the Association for Educational Communications and Technology (AECT), Januszweski et.al.[3] the term of Educational Technology (ET) refers to the study and ethical practice of facilitating learning, and improving performance by creating, using and managing appropriate technological processes and resources.

\subsubsection{The presence of educational technology}

Educational technology refers to the use of both physical hardware and educational theoretic. It encompasses several domains, including learning theory, computer-based training, online learning, and, where mobile technologies are used, m-learning [4].

It is interesting to discuss further related to Educational Technology since many experts have indicated it as an important element in educational process. Some experts cited educational technology is the effective use of technological tools in learning. As a concept, it concerns an array of tools, such as media, machines and networking hardware, as well as considering underlying theoretical perspectives for their effective application.Richey 2008[5] Educational technology includes numerous types of media that deliver text, audio, images, animation, and streaming video, and includes technology applications and processes such as audio or video tape, satellite TV, CD-ROM, and computer-based learning, as well as local intranet/extranet and web-based learning. Information and communication systems, whether free-standing or based on either local networks or the Internet in networked learning, underlie many e-learning processes. Tavangarian et al.[6] defined educational technology as "the study and ethical practice of facilitating learning and improving performance by creating, using and managing appropriate technological processes and resources".

The modernization of education has changed the paradigm of school activities both in and out of the classroom in which the students and the teachers are experienced in a number of activities that need the involvement of the technology information. One of the changes emerged by the presence of educational technology is the teaching and learning activities become more student-centred learning. In this case, the student has great opportunity to study independently. It is in line with Pannen et al.[7] stated that using IT in teaching, the paradigm on the learning has been changed, the process of learning do not fully hundred percent depend on teacher (teacher's-centred learning), however, it becomes more a student-centred learning. Teachers are no longer the only one of the learning resources but more to be as facilitator.

The use of educational technology in the teaching and learning process is not only merely helping the teacher in conducting the teaching process, especially during this pandemic time, but the more important is to facilitate the students and making easier for them in understanding the lesson. The students have large opportunities in learning from various resources through the internet.

Educational Technology as it is mentioned above have been commonly implemented at Senior High Schools in Central Sulawesi, although the result of implementation still far from ideal. In particular, most senior high schools in Palu have applied education technology media to suport the teaching and learning process. Teachers were involved in a short training; In House Training, and Local Educational Training on operating educational technology media. The training was intended to empower the teachers with sufficient knowledge in applying educational media to make them easier to deliver lesson both in the 
classroom and in distance. The students were encouraged to be more proficient in using educational media.

\subsubsection{The advantage of educational technology}

Modern educational technolgy has its potential in schools (for teaching and learning process), examintion (for students' work), research (to enrich findings in education). The main purpose educational technolgy is to overcome conventional problem scale through online anytime and anywhere [8].

Applying educational media in the teaching learning process have some advantages to support teachers and students to interact to each other. This is the more general usefulness of the technology media we can identify in the teaching and learning process. More specifically, the advantage of educational media to institution, teachers and students are as follows:

a. Revitalizing and reorienting existing resources

- Capitalize on the existence of a large number of institutions and facilities, nationwide networks, and trained, professional, and creative manpower in the area of ET. Re-engineer and convert all of these into a potent system.

- Encourage these institutions to take up new roles, including action research, data collection, inservice training of teachers, networking to establish and coordinate nationwide efforts in education, evaluation research, developing models for interactive classes, interactive multimedia, teleconferencing, video conferencing, and in leading the process whereby materials can be generated by teachers, parents, and children at every level.

- Invest in continuous, on-demand teacher training and support, research and content repositories, value-added distance education and online campuses, all of these steps aimed at increasing

- $\quad$ access to, and equity and quality of education.

b. In refreshing skills of in-service teachers

- Create a system of lifelong professional development and support, especially for educational leaders and managers such as headmasters and principals.

- Encourage ICT literacy for official and personal use to build comfort and later creativity in educational work.

- Support the development of and nurture teachers' self-help groups / professional development groups both on the ground and online. c. In school education

- Move from a predetermined set of outcomes and skill sets to one that enables students to develop explanatory reasoning and other higher-order skills

- Enable students to access sources of knowledge and interpret them, and to create knowledge rather than be passive users. The students can construct knowledge by searching for the information via internet.

- Promote individual learning styles. EduTech is able to provide a support for students to study independently, to construct information to be meaningful knowledge and to enhance individual skill and competence.

- Encourage use of flexible curriculum content, at least in primary education, and flexible models of evaluation.

The fact above has commonly found at schools institution in Indonesia, it includes in schools in Central Sulawesi. Teachers have long been introduced to use educational media in the teaching learning process. The use of educational technology is of course unavoidable, many schools institution in Central Sulawesi, particularly in Palu have relied teaching and learning component on the superiority of educational technology media. Educational media is very useful in providing teaching media, teaching strategy, learning evaluation scheme, and final report. Online learning has now come into new period at all schools in Palu, mainly in the period of the outbreak of corona virus pandemic.

\section{BACKGROUND}

\subsection{Distance Learning}

Online learning or education is oriented to cover the rural areas. It is one of educational disciplines that provides access to for the learners and teachers to interact to each other in terms of the fulfilment of education needs. They can communicate asynchronously and synchrounously. It can be described that syncronous communication (teaching and learning process) is a real-time communication between students, peers and teacher. For example, face to face phone communication, online chat, video conferences, and shared whiteboard. Meanwhile, asyncronous is a procss of communication (teaching and learning process) distantly between the teacher and students involved in on line communication indirectly; for exmple e-mail, discussion forums, reading and writing online document through world wide web, blog [9] [10]. Another definition of distance learning is E-Learning is the employment of technology to facilitate and enhance learning. 


\subsubsection{The advantages of distance learning}

The purpose of distance learning is to provide assistance to the stdents in remote areas and for the students who could not join ground learning (common learning) in the classroom in order to be more actively participate in learning educational tasks. The statement above is in line with Traxler [11]; distance provides learners to learn from distance anytime, anywhere and from anyone.

The modern learning educational technology media mediates institutions/schools to empower educational process more reachable and adaptable. The advantage of distance learning, the so called e-learning offers some easiness for institutions, teachers and student to conduct and to participate in educational process. The following are the advantages of distance learning:

- Distance learning to make it possible for the students to study at home or at the place where they feel covinient and there is avaiability of internet connection.

- Online learning provides more experience for students to study independently to achieve learning goals. It leads them to find learning content directly and discuss it with other learner using the IT. Moreover they can study colaboratively, they can share and receive information from other friends.

- The students can complete learning tasks wherever and whenever they are. They can renew learning information quickly without waiting for the next learning experience.

- $\quad$ Studying from distance will accustome students to manage time for learning, besides they can safe from any disruption from fearing of particular disease or threats by using internet to get information.

Based on theoretical perspective, the advantages of distance learning have now become more visible. Responding to the outbreak of corona virus pandemic, distance learning becomes the only choice to keep the teaching and learning process running. The teachers are also still can control their student progress distantly from

\section{FINDINGS AND DISCUSSION}

There is approximately 68.729.073 Million students in Indonesia are forced to study at home due to Covid 19 Pandemic. In Palu it is Approx. 400 schools are closed and 35.000 students are students of Kindergarten, Elementary, any device. The usefulness of distance learning can be identified from the real condition where traditional learning is not possible conducted. In short distance learning is valuable for students and teachers to study and to teach from anywhere anytime, saving significant amount of money, no communiting, flexibility, saving time, and earn while learning [12].

\subsubsection{Distance learning during corona virus pandemic}

The most shocking issue in this millennium is the outbreak of corona virus pandemic on December 2019 that most nations in the world were forced to take significant steps to avoid the most serious impacts. It was not only human health and economical aspects experienced in the serious impact of corona virus pandemic; but also human educational aspect. This situation has required professionals, experts, and health practitioners to find solution in order to keep sustainable world education service running.

Although it is still under threat of corona diseases, most schools in Palu - Central Sulawesi keep doing the teaching and learning process distantly. The local government instructed to conduct educational process by implementing distant learning process. Based on the instruction, school institutions take necessary step before conducting elearning process.

a. Schools provides e-learning media to support the teaching and learning process

b. School staffs are involved in short training to apply e-learning media

c. Conducting in house training for teachers and practitioners to apply educational technology tools.

d. Students are instructed to individually connect personal cellular phone to school connections to support the process running well.

e. Parents are informed to provide children with necessity to mediate them to school educational process.

and Secondary Schools are sent to home learning. Meanwhile, more than 15.000 Senior High School students were suggested to home learning. Based on the situation, the local government of central Sulawesi instructed the schools to conduct In House Training for teachers to apply technological media for teaching and learning process. 
Table 1 In House training for senior high schools teachers

\begin{tabular}{|c|c|c|c|}
\hline $\begin{array}{c}\text { Number of } \\
\text { Senior High } \\
\text { Schools }\end{array}$ & $\begin{array}{c}\text { Number of } \\
\text { Teachers }\end{array}$ & $\begin{array}{c}\text { Actively } \\
\text { Participate }\end{array}$ & $\begin{array}{c}\text { Less Active } \\
\text { Participate }\end{array}$ \\
\hline 9 & 700 & 550 & 150 \\
\hline
\end{tabular}

The less active teachers are those who categorized senior teacher aged range between 55-60. They had less motivation to study because they were not quite familiar with educational technology tool.

Table 2 Students participation in distance learning

\begin{tabular}{|c|c|c|}
\hline Number of Students & Actively Participate & $\begin{array}{l}\text { Less Active } \\
\text { Participate }\end{array}$ \\
\hline 15.000 & 12.000 & 3000 \\
\hline
\end{tabular}

The less active students were caused by some problems in participating into distance learning; internet connection

\subsection{The Advantages of Educational Technology for Teachers}

- Encouraged to learn how to operate IT tools in response to individual teaching preparation for distance learning.

- The teaching and learning process still can be conducted through distance learning.

- The teachers are still consistent to do their responsibility as teacher because he/she can do teaching from home.

- Flexibility of the time and place for the teachers and students in learning activities.

\subsection{The Disadvantages of Educational Technology for Teachers}

- Lack of effective training for teachers. The teachers are less competence in using IT media due to lack of effective training. The training should not only focused on technology skill but also more concerned on pedagogical skill.

- Teacher resistant to change. The teachers are reluctant to change their teaching style due to they have limited time to learn how to operate IT media and how to integrate it into their teaching and learning process.

- Limited facilities such as internet connection and the availability of personal computer.

- The teacher can not controll students' misbehaviour directly.

- Different capacity of to understand the lesson in distance learning. The students have different problem, learning adaptation problem, and the competence in receiving distant lesson.

- Most of teachers do not have sufficient competence to design and prepare lesson material for e-learning.

\subsection{The Advantages of Educational Technology for Students}

- Improved engagement.

They are encouraged and motivated to participate in distance learning, they are curious to study in different situation from their experience before study in the classroom.

- Encouraged individual learning. Technology provides great opportunities for individual students for independent learning.

- Cooperative and collaborative learning. (21 $1^{\text {st }}$ century skill). The use of educational technology in the learning process provides learners not only joyfyl environment, but also an effective environment which they are able to exchange the information and share educative information.

\subsection{The Disdvantages of Educational Technology for Students}

- Unequal facilities of IT tools possessed by the students, and the internet connection at home.

- Students learning style. Most students still depend on the presence of the teacher directly to teach them face to face.

level ability to understand the lesson presented through the distance learning platform. 


\section{CONCLUSION}

The use of EduTech for distance learning during the Covid pandemic has advantages and disadvantages both for teachers and students. Distance learning by using EduTech media is not only how to deliver the lesson to students, but the most important thing is how teachers design interesting teaching material, proper teaching procedure to involve all students in the learning activities. The less participation teachers need serious attention from the colleagues, governments to empower them with sufficient competence in using educational technology tools. The less participation students need to be facilitated by parents, teachers and government.

\section{ACKNOWLEDGMENT}

This work was particularly supported by Muhammadiyah University of Palu, Central Sulawesi, Indonesia.

\section{REFERENCES}

[1] UNESCO: Coronavirus Impacts Education https://en.unesco.org/themes/educationemergencies/coronavirus-school-closures2 Information crowd-sourced from teams across the World Bank

[2] "COVID-19 Educational Disruption and Response". UNESCO. 2020-03-04. Retrieved 2020-04-12.

[3] Januszewski \& Molenda, 2008; Reiser \& Dempsey, 2007; Seels \& Glasgow, 1998; Seels \& Richey, 1994). Instuctional technology The definition and domains of the field.

[4] Biswal, B. Panda, S. Educational Technology and Instructional Technology. EducationalTechnology Paper X - DDCE, Utkal University

[5] Richey, R.C.(2008), "Reflections on the 2008 AECT Definitions of the Field, TechTrends, Vol.52, Issue 1
[6] Tavangarian, Djamshid; Leypold, Markus E.; Nölting, Kristin; Röser, Marc; Voigt, Denny. Is e-learning the solution for individual learning. The Electronic Journal of e-Learning , v2 n2 p273-280 2004.

[7] Pannen, Paulina and Lien, Diao Ai.2005. Information Literacy in Indonesia.http://www.aptik.or.id/artikel/INFOR MATION\%20LITERACY\%20IN\%20INDONESIA 1.pdf. Downloaded July 2020

[8] National Focus Group On Educational Technology; National Council of Education Research and Training. 2006. I Ipek, R Ziatdinov - arXiv preprint arXiv:1808.06063, 2018 - arxiv.org

[9] Distance Education Models and Best Practices. 1101 Pennsylvania Ave. NW, Suite 600 Washington, DC 20004 P 202.756.2971 F 866.808.6585 www.hanoverresearch.com

[10]Al-Arimi, A.M.AK, Distance Learning. Published by Elsevir Ltd. Open Access Article under CC BY-NC-ND Licence (2014): http://creativecommons.org/licences/by-nc$\mathrm{nd} / 3.0 /$

[11]Traxler, J. Article Distance LearningPredictions and Possibilities. Professor of Digital Learning, Institute of Education, University of Wolverhampton, Wolverhampton WV1 1LY, UK; john.traxler@wlv.ac.uk Received: 30 December 2017; Accepted: 1 March 2018; Published: 8 March 2018

[12] Sadeghi International Journal of Research in English Education (2019) 4:1International Journal Od Research in English Education (IJREE) 